\title{
SIMBES, APLIKASI MANAJEMEN BEASISWA DI UNIVERSITAS DIPONEGORO BERBASIS FRAMEWORK CODE IGNITER DAN MYSQL
}

\author{
Muchamad Shodiq ${ }^{1)}$, Kodrat Iman Satoto ${ }^{2)}$, Rinta Kridalukmana ${ }^{3}$
}

Program Studi Sistem Komputer, Fakultas Teknik, Universitas Diponegoro

Jln. Prof. Sudharto, S.H, Tembalang, Semarang, Indonesia

Email : mshodiq27@ce.undip.ac.id

\begin{abstract}
ABSTRAK
Beasiswa merupakan kebutuhan yang sangat penting bagi kalangan pelajar untuk dapat meneruskan pendidikannya terutama bagi golongan yang kurang mampu maupun berprestasi. Universitas Diponegoro sebagai salah satu lembaga pendidikan Negara selalu berusaha memberikan bantuan berupa beasiswa kepada mahasiswanya untuk dapat melaksanakan studi mereka. Akan tetapi, dalam distribusi beasiswa tersebut sering kali mengalami banyak kendala yang dialami oleh mahasiswa seperti waktu yang terlalu mendadak, kesulitan dalam melengkapi persyaratan dan lainnya. Aplikasi Sistem Informasi Beasiswa Universitas Diponegoro merupakan salah satu cara untuk dapat mengatasi kendala distribusi beasiswa di Universitas Diponegoro. Aplikasi ini membantu Universitas Diponegoro dalam meningkatkan kecepatan dan manajemen dalam distribusi beasiswa kepada mahasiswanya.

Tahapan dalam pembuatan aplikasi ini menggunakan beberapa tahap yaitu studi pustaka dan bimbingan, pengambilan data dan analisa (wawancara, pengamatan dan berkas informasi), perancangan, pembuatan system/aplikasi dan terakhir implementasi yang biasa disebut sebagai metode waterfall. Metode ini sangat tepat dalam penelitian aplikasi seperti ini karena mempunyai alur yang memungkinkan perancang untuk mengevaluasi aplikasi tanpa harus mengubah dari dasar. Sedangkan dalam perancangan aplikasi menggunakan pemodelan UML.

Aplikasi ini dibuat berdasarkan framework code igniter yang mengunakan metode MVC (Model, View, Controller) dengan setiap event aplikasi diatur oleh fungsi (function) tertentu di dalam controller. Dalam tahap pengujian, aplikasi diuji dalam lingkup fungsi-fungsinya. Hasilnya, setiap fungsi dapat berjalan dengan lancar dan aplikasi Sistem Informasi Beasiswa dapat diimplementasikan. Aplikasi Sistem Informasi Beasiswa ini dapat berjalan lancar dalam framework code igniter berserta fungsifungsinya. Akan tetapi, aplikasi ini tidak sepenuhnya menggunakan bahasa pemrograman PHP dalam menjalankan fungsinya, ada bahasa Javascript yang bekerja disisi klien yang membantu dalam menjalankan fungsi tertentu. Untuk itu disarankan jangan menonaktifkan fitur javascript di browser pengguna (user) atau akan berdampak aplikasi ini tidak bekerja dengan baik.
\end{abstract}

Kata kunci : sistem informasi, beasiswa, informasi, mahasiswa

\section{PENDAHULUAN}

\subsection{Latar Belakang}

Mahasiswa dalam menjalankan proses belajar, selalu menuntut kemudahan dan kecepatan dalam layanan terutama di dalam Universitas mereka masing-masing. Penyaluran beasiswa kepada mahasiswa adalah salah satu layanan yang dapat diberikan universitas kepada mahasiswanya. Dalam menunjang kelangsungan studi mahasiswanya, Universitas Diponegoro tidak sedikit memberikan bantuan berupa beasiswa. Beasiswa ini sangat membantu dalam proses pendidikan, akan tetapi distribusinya terkadang kurang maksimal.
Cara konvensional yang digunakan oleh Universitas Diponegoro dalam distribusi beasiswa tersebut mempunyai banyak kendala yang hasilnya sering menyusahkan mahasiswa itu sendiri dalam melakukan pendaftaran. Pertama adalah waktu dari beasiswa itu sendiri, terkadang pemberitahuan dari beasiswa tersebut sering mendadak dan mempunyai jangka waktu pendek sampai pengumpulan akhir sehingga mahasiswa yang sedang diluar kampus sering terlambat dalam mendaftar. Kemudian kendala yang lain yaitu berupa kesulitan mahasiswa dalam mencari persyaratan beasiswa itu sendiri. Di sisi bidang kesma, sebagai pengelola distribusi beasiswa, tidak sedikit mengalami kendala 
juga terkait berkas-berkas yang dikumpulkan oleh pendaftar, seperti nomor rekening dari mahasiswa yang sama antara mahasiswa satu dengan yang lain, keterlambatan data pendaftar yang masuk dari masing-masing fakultas.

\subsection{Tujuan}

Tujuan dari tugas akhir ini adalah membuat perangkat lunak sistem informasi beasiswa berbasis web untuk membantu dalam manajemen dan distribusi beasiswa di Universitas Diponegoro kepada mahasiswanya.

\subsection{Pembatasan Masalah}

Untuk menyederhanakan pembahasan pada Tugas Akhir ini, masalah dibatasi sebagai berikut :

1. Pembuatan sistem informasi ini menggunakan bahasa pemrograman PHP dalam lingkup framework Code Igniter, JQuery, basis data MySQL dan bahasa dasar website yaitu HTML dan CSS.

2. Sampel proses pendaftaran beasiswa yang digunakan adalah proses pada beasiswa PPA dan BBM di Universitas Diponegoro.

3. Aplikasi Sistem Informasi Beasiswa ini hanya memiliki lingkup Universitas Diponegoro jenjang D3 dan S1.

\section{DASAR TEORI}

\section{Unified Modeling Language (UML)}

UML merupakan bahasa visual untuk pemodelan dan komunikasi mengenai sebuah sistem dengan menggunakan diagram dan teks-teks pendukung. UML hanya berfungsi untuk melakukan pemodelan. Jadi penggunaan UML tidak terbatas pada metodologi tertentu, meskipun kenyataannya UML paling banyak digunakan pada metodologi berorientasi objek.

\section{PHP Hypertext Preprocessor (PHP)}

PHP merupakan singkatan dari $P H P$ Hypertext Preprocessor yang merupakan bahasa berbentuk skrip yang ditempatkan pada server dan diproses di server. Hasilnya kemudian dikirimkan ke browser klien ${ }^{[2]}$.

\begin{abstract}
JQuery
JQuery merupakan sebuah Javascript Library atau bisa disebut juga sebagai pustaka dari kumpulan kode javascript yang siap pakai. Dalam arti sederhana, JQuery dapat digunakan untuk meringkas sebuah kode javascript yang panjang dalam sebuah proyek pembuatan website. Sehingga sebagai developer web, akan diberikan kemudahan dalam menghadapi bagian yang mengandung javascript. JQuery merupakan program yang berjalan pada sisi klien.
\end{abstract}

\section{Basis Data MySQL}

$M y S Q L$ adalah sebuah perangkat lunak sistem manajemen basis data SQL atau DBMS yang multithread, multi-user dengan sekitar 6 juta instalasi di seluruh dunia. $M y S Q L A B$ membuat $M y S Q L$ tersedia sebagai perangkat lunak gratis di bawah lisensi GNU General Public Licence (GPL). Tetapi mereka juga menjual di bawah lisensi komersial untuk kasus-kasus di mana penggunaannya tida cocok dengan pengunaan $\mathrm{GPL}^{[3]}$.

\section{Framework Code Igniter}

Code Igniter adalah aplikasi open source yang berupa framework dengan model MVC (model view controller) untuk membangun website dinamis. Dengan menggunakan PHP Code Igniter akan memudahkan developer untuk membuat aplikasi web dengan cepat dan mudah dibandingkan dengan membuatnya dari awal.

\section{PERANCANGAN SISTEM}

Sistem informasi yang baik tidak lepas dari sebuah perancangan yang matang dan terstruktur. Layaknya membuat sebuah bangunan, tentulah dibutuhkan sebuah blueprint supaya bangunan tersebut dapat tepat sasaran dan tepat guna. Oleh karena itu, dalam penelitian aplikasi tugas akhir ini, penulis menggunakan metode waterfall. Metode ini terdiri dari beberapa tahap yaitu analisa kebutuhan (requirements), analisa (analysis), desain (design), implementasi (implementation) dan pengujian (testing).

\section{Analisa Kebutuhan}

Pada analisis kebutuhan bertujuan untuk mengumpulkan kebutuhan-kebutuhan 
pengguna dan kemudian mentransformasikan ke dalam sebuah deskripsi yang jelas dan lengkap.

Secara umum, Universitas Diponegoro bagian Kesejahteraan Mahasiswa merupakan bagian dari bidang di rektorat dalam melayani kesejahteraan mahasiswa, salah satunya adalah layanan beasiswa. Demi mempermudah dan menunjang distribusi layanan beasiswa ke mahasiswa, maka diperlukan sebuah website yang mampu melayani mahasiswa dalam bidang beasiswa dan melayani pihak kesma (kesejahteraan mahasiswa) rektorat dalam manajemen dan monitoring distribusi beasiswa tersebut.

Ada beberapa tahapan yang dilakukan kesma universitas dalam mendistribusikan informasi beasiswa dari universitas sampai fakultas dan diterima mahasiswa. Tahapan tersebut adalah :

1. Distribusi informasi beasiswa dari kesma universitas ke fakultas.

2. Distribusi informasi beasiswa dari kesma fakultas ke mahasiswa (dapat melalui web dan organisasi mahasiswa khususnya BEM)

3. Proses pendaftaran

4. Proses penerimaan

5. Proses pengumuman tiap fakultas.

6. Proses laporan kesma fakultas ke kesma universitas.

\section{Analisa Sistem}

Tahap analisis sistem bertujuan untuk menjabarkan segala sesuatu yang nantinya akan ditangani oleh perangkat lunak. Tahapan ini berisi analisa dari permasalahan yang ada pada tahap sebelumnya, meliputi aktor yang terlibat dalam sistem, kebutuhan fungsional dan kebutuhan aplikasi yang muncul berdasarkan kendala yang ada.

Ada beberapa aktor/pengguna pada sistem ini yaitu super admin, admin (universitas dan fakultas), mahasiswa dan umum. Sedangkan dari segi operasional, aplikasi ini memerlukan kebutuhan minimum yaitu sistem operasi (hampir semua sistem operasi dapat menggunakan aplikasi ini asalkan dilengkapi dengan web server), PHP versi 5.1.6, basis data seperti MySQL 4.1+, MySQLi, MS SQL, Postgres, Oracle,
SQLite, dan ODBC dan tidak lupa yaitu web browser.

\section{Rancangan / Desain}

Tahap perancangan perangkat lunak (design) merupakan proses yang berfokus pada beberapa atribut yang ada di perangkat lunak. Proses ini menerjemahkan kebutuhan ke dalam sebuah model perangkat lunak dan berdasarkan analisis sistem sebelumnya menghasilkan rancangan yang berisi ERD (Entity Relationship Diagram), UML, dan desain antar muka.

Entity Relationship Diagram (ERD) adalah salah satu metode pemodelan perangkat lunak yang biasanya digunakan dalam tahap analisis perancangan basis data. ERD berupa model data konseptual yang merepresentasikan data tertentu. Salah satu contoh ERD yang ada dapat dilihat pada gambar 3.1.

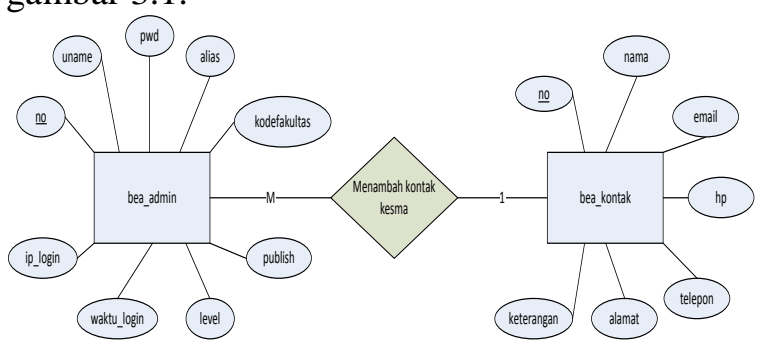

\section{Gambar 3.1 Relasi entitas bea_admin dan bea_kontak}

Tahap selanjutnya adalah membuat UML dengan alur pertama yaitu membuat definisi aktor, kemudian dilanjutkan dengan definisi use case, membuat diagram use case, membuat diagram objek, dan membuat diagram sekuen. Pendefinisian use case tersebut tidak lepas dari pendefinisian aktor yang terlibat dalam sistem. Aktor-aktor tersebut dapat dilihat pada tabel 3.1.

Tabel 3.1 Deskripsi pendefinisian aktor

\begin{tabular}{|c|l|l|}
\hline No. & \multicolumn{1}{|c|}{ Aktor } & \multicolumn{1}{|c|}{ Deskripsi } \\
\hline 1. & Super Admin & $\begin{array}{l}\text { Orang yang bertugas dan } \\
\text { memiliki hak akses untuk } \\
\text { melakukan pengelolaan akun } \\
\text { pengguna sistem, mengelola } \\
\text { daftar fakultas dan jurusan, } \\
\text { mengelola akun pribadi serta } \\
\text { memberikan komentar } \\
\text { terhadap suatu berita. }\end{array}$ \\
\hline 2. & $\begin{array}{l}\text { Admin } \\
\text { Pengelola } \\
\text { Tingkat } \\
\text { Universitas ) }\end{array}$ & $\begin{array}{l}\text { Orang yang bertugas dan } \\
\text { memiliki hak akses untuk } \\
\text { melakukan pengelolaan } \\
\text { beasiswa }\end{array}$ \\
\end{tabular}




\begin{tabular}{|c|c|c|}
\hline & & $\begin{array}{l}\text { pencairan, penerimaan dll), } \\
\text { melihat informasi mahasiswa, } \\
\text { mengelola kontak kesma } \\
\text { universitas, mengelola akun } \\
\text { pribadi, mengelola berita dan } \\
\text { komentar, dan mengelola } \\
\text { history sistem. }\end{array}$ \\
\hline 3. & $\begin{array}{l}\text { Admin } \\
\text { Pengelola } \\
\text { Tingkat } \\
\text { Fakultas ) }\end{array}$ & $\begin{array}{l}\text { Orang yang bertugas dan } \\
\text { memiliki hak akses untuk } \\
\text { melakukan pengelolaan } \\
\text { beasiswa (hampir sama } \\
\text { dengan poin nomor 2, akan } \\
\text { tetapi tidak bisa melakukan } \\
\text { penambahan, pencairan serta } \\
\text { hanya mengelola berdasarkan } \\
\text { fakultas tertentu saja), melihat } \\
\text { informasi mahasiswa, } \\
\text { mengelola akun pribadi, dan } \\
\text { menambahkan komentar pada } \\
\text { suatu berita tertentu. }\end{array}$ \\
\hline 4. & Mahasiswa & 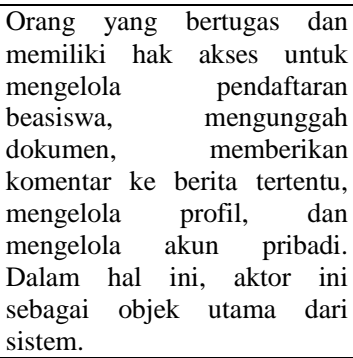 \\
\hline 5. & Umum & $\begin{array}{l}\text { Orang yang memiliki hak } \\
\text { akses sebatas hanya melihat } \\
\text { daftar beasiswa dan berita } \\
\text { atau pengumuman yang ada } \\
\text { tanpa bisa memberikan } \\
\text { komentar apapun. }\end{array}$ \\
\hline
\end{tabular}

Kemudian, ketika aktor yang terlibat sudah dapat diketahui, selanjutnya membuat tingkah laku atau kejadian yang memungkinkan terjadi pada sistem. Hal ini biasanya disebut dengan use case. Salah satu contoh use case yang ada adalah login yang dilakukan oleh aktor sistem dan dapat dilihat pada tabel 3.2.

Tabel 3.2 Skenario use case login

\begin{tabular}{|c|c|c|}
\hline Aksi Aktor & \multicolumn{2}{|c|}{ Reaksi Sistem } \\
\hline \multicolumn{3}{|l|}{ Skenario normal } \\
\hline \multicolumn{3}{|l|}{$\begin{array}{l}\text { 1. } \begin{array}{l}\text { Memasukkan } \\
\text { username dan } \\
\text { password }\end{array} \\
\end{array}$} \\
\hline & & $\begin{array}{lr}\text { Mengecek } & \text { valid } \\
\text { tidaknya } & \text { data } \\
\text { masukan. } & \\
\end{array}$ \\
\hline & & $\begin{array}{lr}\text { Masuk } & \text { ke } \\
\text { aplikasi SIMBES }\end{array}$ \\
\hline \multicolumn{3}{|l|}{ Skenario alternatif } \\
\hline \multicolumn{3}{|l|}{$\begin{array}{l}\text { 1. Memasukkan } \\
\text { username dan } \\
\text { password }\end{array}$} \\
\hline & & $\begin{array}{lr}\text { Mengecek } & \text { valid } \\
\text { tidaknya } & \text { data } \\
\text { masukan } & \\
\end{array}$ \\
\hline & & $\begin{array}{l}\text { Menampilkan } \\
\text { pesan login tidak } \\
\text { valid }\end{array}$ \\
\hline 4. Memasukkan & & \\
\hline
\end{tabular}

\begin{tabular}{|c|c|c|}
\hline $\begin{array}{l}\text { username dan } \\
\text { password yang } \\
\text { valid }\end{array}$ & & \\
\hline & & $\begin{array}{lr}\text { Mengecek } & \text { valid } \\
\text { tidaknya } & \text { data } \\
\text { masukan. } & \end{array}$ \\
\hline & & $\begin{array}{lr}\text { Masuk } & \text { ke } \\
\text { aplikasi SIMBES }\end{array}$ \\
\hline
\end{tabular}

Antar muka pengguna merupakan salah satu hal yang penting karena bagian inilah yang akan berinteraksi dengna pengguna secara langsung. Antar muka pengguna hendaklah dapat semaksimal mungkin bersifat user-friendly, dengan kata lain sebisa mungkin pengguna dapat paham dan nyaman dalam menggunakan aplikasi sekalipun pengguna itu masih awam.

Berikut ini, pada gambar 3.3 adalah salah satu contoh rancangan antarmuka yang ada pada Aplikasi Sistem Informasi Beasiswa :

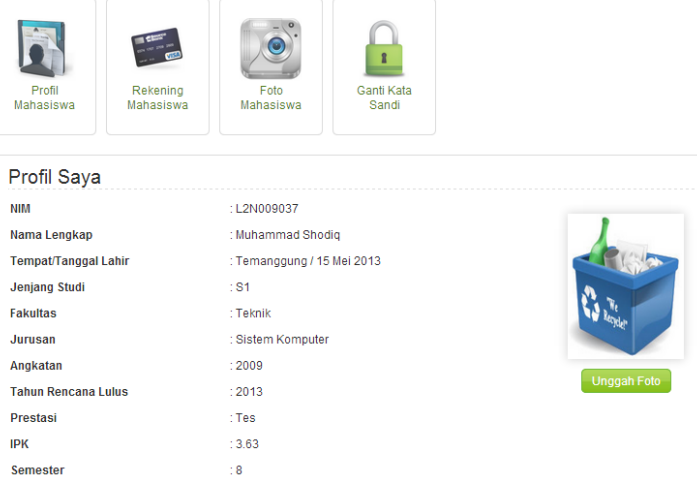

Gambar 3.2 halaman profil mahasiswa

Aplikasi ini tentunya tidak lepas dari kerangka MVC karena menggunakan framework Code Igniter. Dalam perancangannya, desain MVC yang digunakan seperti pada gambar 3.4.

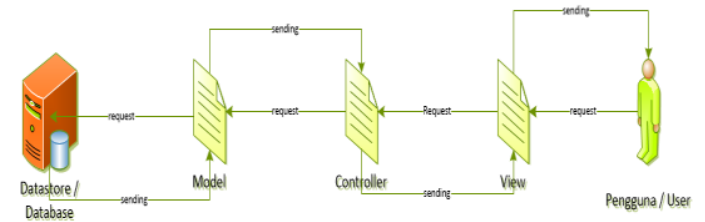

Gambar 3.3 desain MVC aplikasi.

\section{Implemtasi dan Pengujian}

Merupakan tahap mengkonversi apa yang telah dirancang sebelumnya ke dalam sebuah bahasa yang dimengerti komputer. Tahap ini dibagi menjadi implementasi program dan implementasi deployment.

Pada pengujian dilakukan dengan menggunakan metode black-box dengan 
kata lain pengujian menekankan pada fungsionalitas dari aplikasi.

\section{IMPLEMENTASI PENGUJIAN}

DAN

Berdasarkan rancangan dan kebutuhan sistem, proses implementasi dibagi menjadi implementasi tabel dan implementasi progam. Implementasi tabel yaitu mengimplementasikan rancangan tabel ke dalam database sesuai degan analisa sebelumnya menggunakan MySQL. Sedangkan implementasi program berisi potongan kode program yang dibuat agar program berjalan sesuai dengan rancangan analisa di BAB III.

\subsection{Pembuatan Basis Data dan Tabel}

Langkah pertama sebelum membuat tabel yaitu membuat nama database, untuk hal ini penulis memberikan nama dengan "db simbes" yang terdiri dari 19 tabel. Setelah database berhasil dibuat, langkah selanjutnya adalah membuat tabel dengan atribut yang sudah dirancang sebelumnya. Dalam phpmyadmin, seorang developer tidak harus menggunakan kode untuk membuat tabel-tabel tersebut, tetapi hanya perlu mengklik dari menu-menu yang sudah disediakan.

\begin{tabular}{|c|c|c|c|c|c|c|c|}
\hline & Field & Type & Collation & Attributes & Null & Default & Extra \\
\hline$\square$ & $\underline{\text { no }}$ & $\operatorname{int}(11)$ & & & No & None & auto_increment \\
\hline$\square$ & uname & varchar(200) & latin1_swedish_ci & & No & None & \\
\hline$\square$ & pwd & varchar(255) & latin1_swedish_ci & & No & None & \\
\hline$\square$ & alias & varchar(100) & latin1_swedish_ci & & Yes & NULL & \\
\hline$\square$ & kodefakultas & varchar(3) & latin1_swedish_ci & & Yes & NULL & \\
\hline$\square$ & ip_login & varchar(20) & latin1_swedish_ci & & No & None & \\
\hline$\square$ & waktu_login & date & & & No & None & \\
\hline$\square$ & level & enum(admin','root') & latin1_swedish_ci & & No & admin & \\
\hline$\square$ & publish & enum $\left(Y^{\prime}, N^{\prime}\right)$ & latin1_swedish_ci & & No & Y & \\
\hline
\end{tabular}

Gambar 4.1 struktur tabel bea_admin dalam basis data

\subsection{Pembuatan program}

Code Igniter tidak lepas dengan namanya MVC (Model, View dan Controller), oleh karena itu tahapan dalam pembuatan dengan framework ini dapat dianalisa dengan mudah. Langkah pertama adalah membuat model, salah satu contohnya adalah pada gambar 4.2 yaitu model akun.php yang bertugas untuk validasi user.

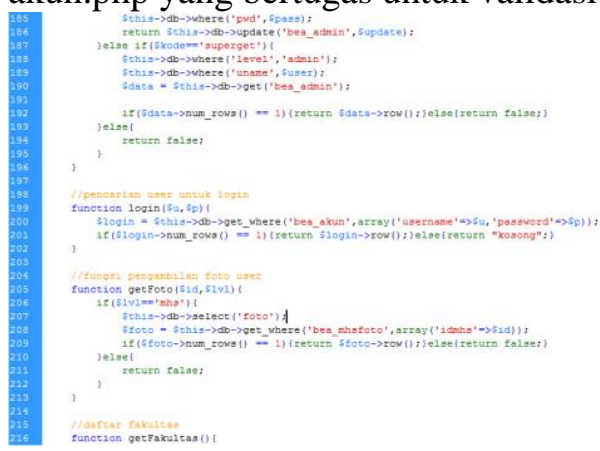

Gambar 4.2 tampilan source code model akun.php dalam dreamweaver

\subsection{Pengujian}

Proses pengujian menggunakan metode black box dibagi menurut fungsi dari masing-masing menu sesuai dengan kegunaannya. Bentuk pengujian berupa cara pengguna menggunakan aplikasi yang dapat dilihat pada tabel 4.1.

Tabel 4.1 Pengujian fasilitas pada aplikasi

\begin{tabular}{|c|c|c|c|}
\hline $\begin{array}{c}\text { Nama } \\
\text { Pengujia } \\
\text { n }\end{array}$ & $\begin{array}{c}\text { Bentuk } \\
\text { Pengujian }\end{array}$ & $\begin{array}{c}\text { Hasil } \\
\text { yang } \\
\text { Diharapk } \\
\text { an }\end{array}$ & $\begin{array}{c}\text { Hasil } \\
\text { Pengujia } \\
\text { n }\end{array}$ \\
\hline Login & $\begin{array}{l}\text { Memasuk } \\
\text { kan } \\
\text { username } \\
\text { dan } \\
\text { password }\end{array}$ & $\begin{array}{l}\text { Muncul } \\
\text { halaman } \\
\text { utama } \\
\text { aplikasi }\end{array}$ & Berhasil \\
\hline $\begin{array}{l}\text { Pengujian } \\
\text { menu } \\
\text { CRUD } \\
\text { berita }\end{array}$ & $\begin{array}{l}\text { Menjalank } \\
\text { an proses } \\
\text { CRUD } \\
\text { pada } \\
\text { berita }\end{array}$ & $\begin{array}{l}\text { Fasilitas } \\
\text { CRUD } \\
\text { berita } \\
\text { berjalan } \\
\text { lancar }\end{array}$ & Berhasil \\
\hline $\begin{array}{l}\text { Pengujian } \\
\text { menu } \\
\text { CRUD } \\
\text { beasiswa }\end{array}$ & $\begin{array}{l}\text { Mengguna } \\
\text { kan } \\
\text { fasilitas } \\
\text { CRUD di } \\
\text { beasiswa }\end{array}$ & $\begin{array}{l}\text { Fasilitas } \\
\text { CRUD } \\
\text { beasiswa } \\
\text { berjalan } \\
\text { lancar }\end{array}$ & Berhasil \\
\hline $\begin{array}{l}\text { Pengujian } \\
\text { menu } \\
\text { tambah }\end{array}$ & $\begin{array}{l}\text { Mengklik } \\
\text { tombol } \\
\text { tambah }\end{array}$ & $\begin{array}{l}\text { Syarat } \\
\text { yang } \\
\text { terpilih }\end{array}$ & Berhasil \\
\hline
\end{tabular}




\begin{tabular}{|c|c|c|c|}
\hline $\begin{array}{l}\text { syarat } \\
\text { beasiswa }\end{array}$ & $\begin{array}{l}\text { syarat dan } \\
\text { memilih } \\
\text { syarat } \\
\text { yang } \\
\text { diperlukan }\end{array}$ & $\begin{array}{l}\text { muncul di } \\
\text { daftar } \\
\text { persyarata } \\
\text { n } \\
\text { beasiswa }\end{array}$ & \\
\hline $\begin{array}{l}\text { Pengujian } \\
\text { menu } \\
\text { tambah } \\
\text { penerima } \\
\text { beasiswa }\end{array}$ & $\begin{array}{l}\text { Mengklik } \\
\text { tombol } \\
\text { tambah } \\
\text { penerima } \\
\text { dan } \\
\text { memilih } \\
\text { pendaftar } \\
\text { yang } \\
\text { menjadi } \\
\text { penerima } \\
\text { beasiswa }\end{array}$ & $\begin{array}{l}\text { Pendaftar } \\
\text { yang } \\
\text { sudah } \\
\text { menjadi } \\
\text { penerima } \\
\text { muncul } \\
\text { pada } \\
\text { daftar } \\
\text { penerima }\end{array}$ & Berhasil \\
\hline $\begin{array}{l}\text { Pengujian } \\
\text { menu } \\
\text { tambah } \\
\text { pencairan }\end{array}$ & $\begin{array}{l}\text { Mengklik } \\
\text { tombol } \\
\text { tambah } \\
\text { pencairan } \\
\text { dan } \\
\text { memasukk } \\
\text { an } \\
\text { informasi } \\
\text { pencairan }\end{array}$ & $\begin{array}{l}\text { Muncul } \\
\text { pesan } \\
\text { berhasil } \\
\text { di- } \\
\text { broadcast }\end{array}$ & Berhasil \\
\hline $\begin{array}{l}\text { Pengujian } \\
\text { menu } \\
\text { cetak } \\
\text { laporan }\end{array}$ & $\begin{array}{l}\text { Mengklik } \\
\text { tombol } \\
\text { cetak } \\
\text { laporan } \\
\text { (PDF dan } \\
\text { Excel) }\end{array}$ & $\begin{array}{l}\text { Muncul } \\
\text { tampilan } \\
\text { (downloa } \\
\text { d) laporan } \\
\text { (PDF atau } \\
\text { Excel) }\end{array}$ & Berhasil \\
\hline $\begin{array}{l}\text { Pengujian } \\
\text { menu } \\
\text { tampil } \\
\text { history }\end{array}$ & $\begin{array}{l}\text { Memasuk } \\
\text { kan range } \\
\text { tanggal }\end{array}$ & $\begin{array}{l}\text { Muncul } \\
\text { tampilan } \\
\text { daftar } \\
\text { beasiswa } \\
\text { berdasark } \\
\text { an range } \\
\text { tanggal } \\
\text { tertentu. }\end{array}$ & Berhasil \\
\hline $\begin{array}{l}\text { Pengujian } \\
\text { menu } \\
\text { profil } \\
\text { mahasisw }\end{array}$ & $\begin{array}{l}\text { Memasuk } \\
\text { kan } \\
\text { informasi } \\
\text { biodata }\end{array}$ & $\begin{array}{l}\text { Muncul } \\
\text { pesan } \\
\text { berhasil } \\
\text { diperbaha }\end{array}$ & Berhasil \\
\hline
\end{tabular}

\begin{tabular}{|c|c|c|c|}
\hline $\mathrm{a}$ & mahasiswa & rui & \\
\hline $\begin{array}{l}\text { Pengujian } \\
\text { CRUD } \\
\text { dokumen }\end{array}$ & $\begin{array}{l}\text { Mengklik } \\
\text { tombol- } \\
\text { tombol } \\
\text { CRUD } \\
\text { dokumen }\end{array}$ & $\begin{array}{l}\text { Proses } \\
\text { CRUD } \\
\text { berjalan } \\
\text { lancar }\end{array}$ & Berhasil \\
\hline $\begin{array}{l}\text { Pengujian } \\
\text { menu } \\
\text { daftar } \\
\text { beasiswa }\end{array}$ & $\begin{array}{l}\text { Mengklik } \\
\text { tombol } \\
\text { "Daftar" } \\
\text { beasiswa }\end{array}$ & $\begin{array}{l}\text { Muncul } \\
\text { pesan } \\
\text { berhasil } \\
\text { mendaftar }\end{array}$ & Berhasil \\
\hline $\begin{array}{l}\text { Pengujian } \\
\text { menu } \\
\text { melengka } \\
\text { pi syarat } \\
\text { beasiswa }\end{array}$ & $\begin{array}{l}\text { Mengklik } \\
\text { tombol } \\
\text { syarat } \\
\text { beasiswa } \\
\text { dan } \\
\text { memilih } \\
\text { dokumen } \\
\text { yang } \\
\text { digunakan } \\
\text { untuk } \\
\text { syarat }\end{array}$ & $\begin{array}{l}\text { Muncul } \\
\text { pesan } \\
\text { berhasil } \\
\text { disimpan }\end{array}$ & Berhasil \\
\hline
\end{tabular}

\section{PENUTUP}

\subsection{Kesimpulan}

Dari hasil pengujian dan analasis aplikasi Sistem Informasi Manajemen Beasiswa, maka dapat disimpulkan hal-hal sebagai berikut.

1. Aplikasi dibangun dengan basis web yang dapat dijalankan oleh pengguna di mana saja dan hanya membutuhkan koneksi internet dan browser.

2. Aplikasi ini menggunakan informasi beasiswa yang secara umum sering digunakan seperti informasi pendaftaran, penutupan, persyaratan, nilai dan kuota.

3. Berdasarkan hasil kuisoner kepada pengguna (mahasiswa), kurang dari 10 $\%$ yang menyatakan aplikasi ini sulit digunakan dan tidak nyaman.

\subsection{Saran}

Berdasarkan pengujian terhadap aplikasi Sistem Informasi Manajemen Beasiswa yang telah dibuat, dapat diberikan beberapa saran sebagai berikut. 
1. Aplikasi Sistem Informasi Manajemen Beasiswa ini dapat dikembangkan lebih lanjut dengan menambahkan beberapa fitur yang belum dimasukkan ke dalam aplikasi.

2. Melakukan backup data secara berkala untuk menanggulangi jika terjadi kehilangan maupun kerusakan data.

3. Penggunaan yang hati-hati ketika menggunakan fitur penghapusan history, karena data akan dipaksa dihapus berdasarkan range tanggal tertentu dan tidak dapat dikembalikan lagi.

\section{DAFTAR PUSTAKA}

[1] Adi, A.P dan Sanjay, R. Web Makin Dahsyat dengan JQuery. Kompas Gramedia. Semarang, 2012.

[2] Hirin A.M dan Virgi., Cepat Mahir Pemrograman Web dengan PHP dan MySQL, Prestasi Pustakaraya, Jakarta, 2011.

[3] Kadir, Abdul., Dasar Pemrograman Web Dinamis Menggunakan PHP, CV. Andi Offset., Yogyakarta, 2008.

[4] Kadir, Abdul., Mastering AJAX dan PHP. CV. Andi Offset, Yogyakarta, 2009.

[5] Kroenke, David M., Database Processing Fundamental, Design, And Implementation. Erlangga. Jakarta, 2005.

[6] Mata, A.Ramon, dkk., Dasar-Dasar Database Relasional. Schaum's Otline Erlangga, Jakarta, 2007.

[7] Saputro, Haris, Manajemen Database MySQL menggunakan MySQL Front, PT. Elex Media Komputindo, Jakarta, 2003.
[8] Septian, Gungun. Trik Pintar Menguasai CodeIgniter., Elex Media Komputindo., Jakarta, 2011.

[9] Solichin, Achmad., Pemrograman Web dengan PHP dan MySQL, Universitas Budi Luhur., Jakarta, 2011.

[10] Wahyono, Teguh., Practice Guide PHP On Windows, PT. Elex Media Komputindo., Jakarta, 2009.

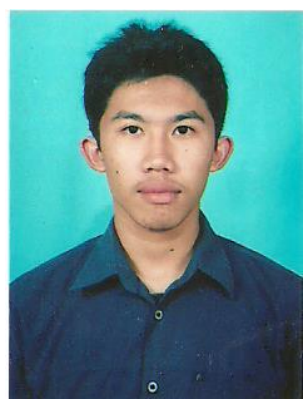

BIODATA

Muchamad Shodiq, lahir di Temanggung 20 November 1990. Pendidikan yang telah ditempuh yaitu TK Aisyiah B.A., SD Muhammadiyah 1 , SMP N 2, dan SMA N 1 yang semua berada di kota Temanggung. Sekarang menyelesaikan pendidikan Strata Satu di Program Studi Sistem Komputer Universitas Diponegoro Semarang, Indonesia angkatan 2009.

Mengetahui/Mengesahkan Dosen Pembimbing I

Ir. Kodrat Iman Satoto, M.T. NIP 196310281993031002

Mengetahui/Mengesahkan Dosen Pembimbing II

Rinta Kridalukmana, S.Kom., M.T. NIP 197706152008011011 